\title{
Strategic Planning in the Construction Companies in Oman
}

\author{
Engr. Layth Dhari Al-Ghrairee
}

MBA Graduate, Middle East College, College, Oman

Email: Eng.laythalgreree@yahoo.com

Article History: Received on $17^{\text {th }}$ Nov. 2020, Revised on $15^{\text {th }}$ Dec. 2020, Published on $8^{\text {th }}$ Jan. 2021

\begin{abstract}
Purpose of the study: The purpose of the study was to critically evaluate the components of the strategic planning process of construction companies in Oman; to investigate the factors that led to the success of strategic planning in construction companies in Oman; to identify the challenges in the implementation of strategic planning among different construction companies' categories in Oman and to make recommendations in enhancing the strategic planning process for construction companies in Oman as well as in minimizing challenges.

Design/Methodology/Approach: This research adopted a mixed approach, quantitative and qualitative approach where it used the quantitative technique to investigate the companies and identify the problem while the qualitative approach was used to explain the challenges and uncover the best practices followed by the companies. The research used the cross-section time horizon data. Out of 940 companies registered as local companies in the category of construction and maintenance, the study tested 90 companies using the survey questionnaire and interviews with senior employees/the owners of the companies.
\end{abstract}

Findings: The study has shown that most of the companies have a clear understanding of the strategic planning components. Companies have realistic strategic plans but improvements need to be done to ensure success during implementation. It was also revealed that the motivation is not at the best level and the lack of creating a sense of urgency to implement the strategic plans which need to be enhanced.

Research Implications: Some recommendations are given also to enhance the work environment and the manager's skills and motivation system in the companies to achieve efficient strategic planning. Some recommendations are regulatory. This is a proposal to the government to do special legislation to regulate and protect private companies from unfair competition.

Social Implications: The success of the strategic plans of the construction companies will lead to the socioeconomic growth of the country. The recommendation will enhance the work environment and the strict implementation of strategic planning processes in construction companies in Oman. It was suggested that the Government need to amend the legislation curbing the unfair competition created by illegal contractors and small companies.

Originality/value: There were no earlier studies discussed more in detail about strategic planning in construction companies in Oman. This study will help the companies' owners and the decision-makers to adopt more successful strategic plans which will lead to greater success of the construction companies to have huge economic growth.

Keywords: Strategic Planning, Strategic Planning Process, Components of strategic planning, Challenges of strategic planning, Construction companies in Oman.

\section{Introduction}

The construction industry plays an important role in the economic growth and long-term national socioeconomic development of any country (Ofori and Toor, 2012). Oman as a developing country is giving great interest and focus on the construction sector, that is how the development has been taking place in all sectors of the country and the related facilities like infrastructure, roads, airports, buildings, and government offices. The concept of strategic planning and its implementation varies among companies as implementation is highly influenced by the type and size of companies, the external and internal environment of the company, as well as the company's tools, techniques, and priorities.

Strategic planning is a process carried out by the organization's leader to determine the vision, goals, and objectives (Rouse and Daellenbach, 1999). Strategic planning is a tool for strategic management and the decision-making process to obtain certain results in the future (Aguila, 2015). It has been defined as a technique that involves the identification of future trends, threats, opportunities, and analysis of the competitions and diversification which may change organizational perceptions based on historical trends (Boateng et al., 2015). This is an organization's process of defining its strategy or direction and making decisions on allocating its resources to pursue this strategy (Cakmak and Tas, 2012). Strategic planning can have a different meaning to different people and organizations, it can have many meanings and outcomes as well. On a basic level, strategic planning could be an articulated plan to naming vision, mission, goals, and objectives, wherein sometimes it is required to consider the external factors and analyses. The strategy could 
mean a drive for organization engagement by cascading goals to make everybody in the organization know what is his or her role in the plans.

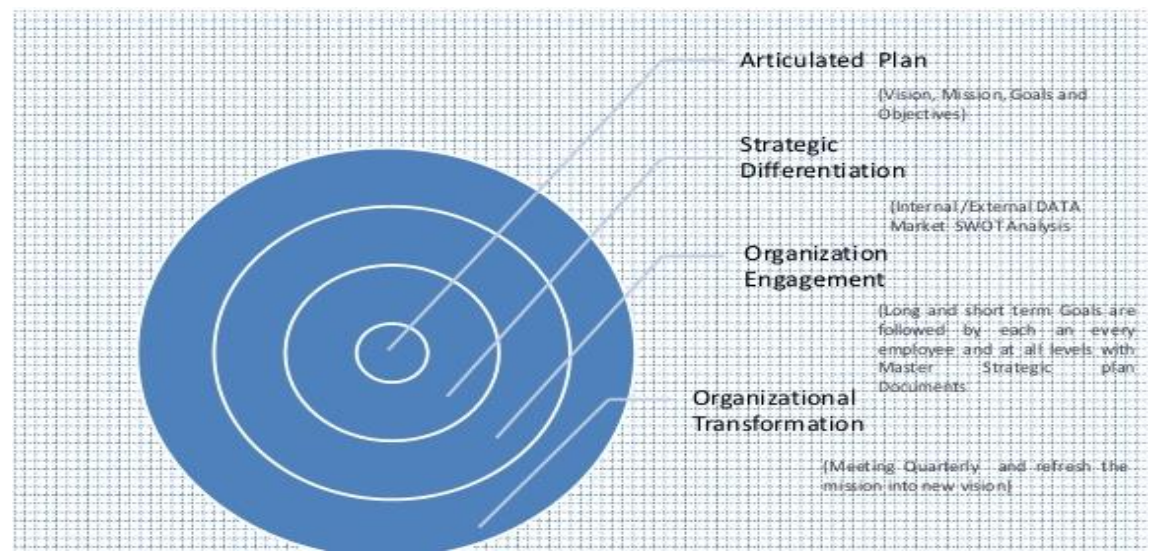

Fig.1 Theoretical Framework for Strategic Planning (Rouse and Daellenbach, 1999)

From Fig.1, it can be observed that the strategic planning process is an articulated plan to guide the decisionmaking about the organization's directions. Strategic planning includes three levels viz. corporate-level strategy, business unit-level strategy, and market-level strategy (Sage, 2020). Strategic planning in construction is always built on the technological and social factors as a base to make the decisions, and this is usually done by the top management informally.

\section{Statement of the Problem}

Without good and solid strategic planning, companies cannot achieve huge success in their businesses. So, the main issues faced during strategic planning need to be analyzed. Thus it is important to focus on the role of strategic planning in the construction companies in Oman, as it is necessary to discuss the huge role of the construction industry in the economic growth of the country and its long-term national socio-economic development. It is necessary to find out solutions as that will help to overcome these issues and will lead to having more successful companies in the construction sector which in turn will have a positive socioeconomic impact in the long term.

The study ensures that the components of strategic planning in the different categories of companies are understood by the employees and stakeholders, and the success factors of strategic plans and the challenges will help to explore the stated elements. This will help to identify the missing factors required to achieve success as well as the challenges of strategic planning implementation. Therefore, the recommendations and suitable solutions to enhance the strategic planning process were considered.

This research identifies the challenges in the implementation of strategic planning usually faced during implementing strategic planning viz. weak strategy, ineffective training, lack of resources, lack of communication; and lack of follow-through (Dalum, 2018). The study analysed these challenges and how companies will resolve these challenges and then the recommendations on good practices and resolutions to challenges were presented through the study. The recommendations aimed not only to minimize the challenges but also to enhance the strategic planning practices in the construction companies in Oman. These practices lead to the success of strategic planning: pull together a diverse, yet appropriate group of people to make up your planning team, allow timing for the big picture, strategic thinking, get full commitment from key people in the organization, allow for open and free discussion regardless of each person's position within the organization, think about execution before, using a facilitator, making an actionable plan, not to write the plan in stone, clearly articulate steps after every session; and make the strategy as a habit rather than just a retreat (Perkins, 2020).

\section{Research Questions}

The following research questions were raised during the research study:

1. What are the components of the strategic planning process in construction companies in Oman?

2. What are the factors that led to the success of strategic planning in construction companies in Oman?

3. What are the challenges faced when implementing the strategic planning process among different construction companies' categories in Oman? 
4. What are the appropriate solutions that can be recommended to minimize the challenges in the implementation of the strategic planning process as well as in enhancing such a process?

\section{Research Objectives}

This research aimed to critically study and evaluate the role of strategic planning in construction companies in Oman. The primary objectives were:

1. To make a critical evaluation of the components of the strategic planning process of construction companies in Oman.

2. To investigate the factors that led to the success of strategic planning in construction companies in Oman.

3. To identify the challenges in the implementation of strategic planning among different construction companies' categories in Oman.

4. To make recommendations in enhancing the strategic planning process for construction companies in Oman as well as in minimizing challenges.

\section{Review of Literature}

Strategic planning is the art of making, implementing, and evaluating decisions that enable organizations to achieve their long-term objectives (Asakereh and Bahrani, 2012). Strategic planning is an organization's process of defining the strategy, direction, or decision-making and allocating the required resources (Haythem, 2015). Strategic planning is a disciplined effort to produce fundamental decisions and actions shaping the nature and direction of an organization's activities within the legal bound (Boateng et al., 2015). Strategic planning would go out for ten years, but the companies usually do it for 2-3 years only and even some of the companies do it for one year only (Lotich, 2019). Strategic planning is considered a key element of the organization's management in achieving business sustainability and better competitive advantage (Chaudhry et al., 2012).

The importance of strategic planning and its relationship with organizational performance had mixed outcomes (Jayawarna and Dissanayake, 2019). Strategic planning benefits through achievable improved performance, good communication process, teamwork, and making a sense of pride (IC Thrive, 2016).

\section{Strategic Planning Process}

The strategic planning process is to direct the vision and mission and implementing a strategy to achieve the goals and objectives of the company (Taylor, 2015). The strategic planning process is a comprehensive process to analyze the status and implement the formulated strategy and evaluate it (Jurevicius, 2013). The process should be transparent with documentation to all information from start till finish (Rouse and Daellenbach, 1999). The strategic planning process is an ongoing process in which a company's leaders decide on the future development and the required procedures to achieve the goals (Haythem, 2015). The strategic planning process includes five steps-initial assessment, current situation analysis, strategy formulation, strategy implementation, and monitoring (Lotich, 2019).

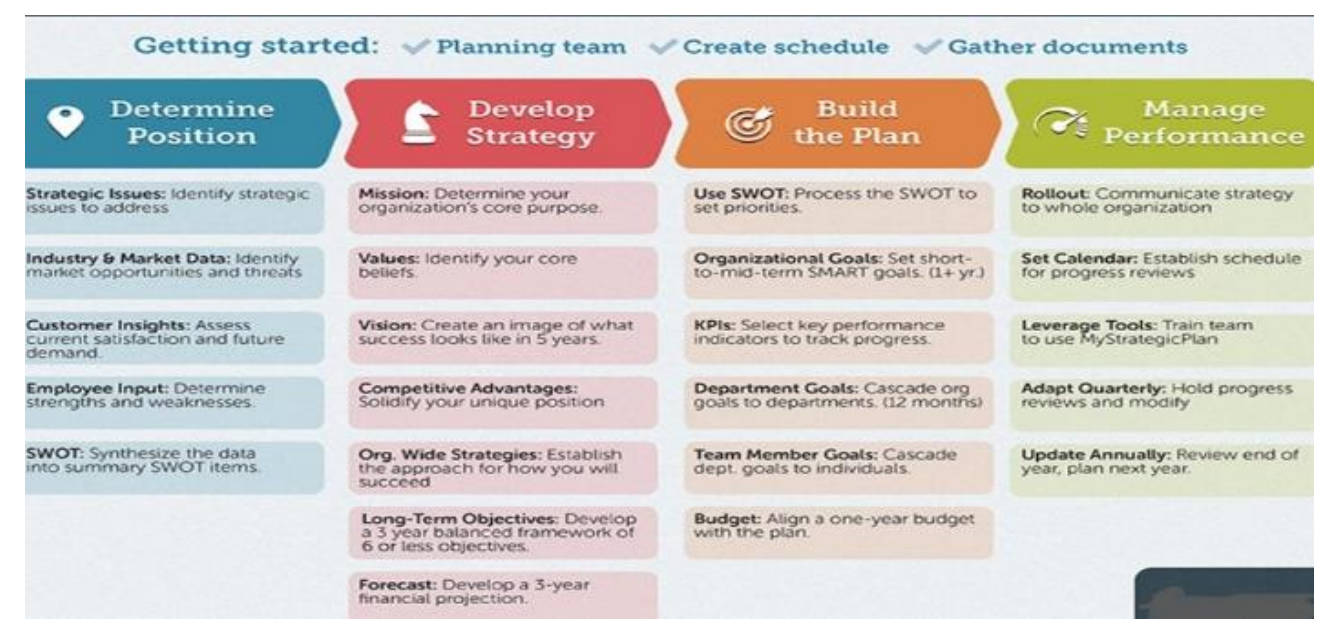

Fig.2 Strategic Planning Process (Jurevicius, 2013)

\section{Construction Companies and Strategic Planning}

The best way to write the strategy of a construction company is to focus on four elements viz. communication, resource identification, tracking progress and conflict mediation, and reporting Workfront (2020). Strategic plans in the construction companies provide transparency and clarity for the entire team and all project stakeholders (Workfront, 2020). Cherkaoui (2020) suggested a six-step framework for the preparation of a 
strategic plan viz. Studying the Company Mission, Examining the Business Environment of the Company, Analysis of the company's resources, Developing a Strategy, Aligning and Executing the Strategy, Review, Measure and Modify the strategy.

\section{Components of Strategic Planning}

Each strategic plan should contain key components, vision, and mission statement, goals, and objectives, action plan, and scorecard (Vo, 2019). Olsen (2016) confirmed that a strategic plan should include mission, vision and values statement, SWOT, competitive advantage, long-term strategic objective, strategies, shortterm goals and priorities, action plan, scorecard, and finance assessment. Jurevicius (2013) claimed that the additional essential components of the strategic planning process are competitor analyses, business-level plan, corporate level plan, global strategy selection, annual objectives, policies., resources allocation, change management, organization chart, and linking performances.

\section{Factors for Successful Strategic Planning}

Watson (2016) stated that strategic planning is a collective task, should be inclusive, include real facts, should have a measure to evaluate the progress, and should be linked to the organization's profit and loss. Cherniss (2018) pointed out the key factors for successful strategic planning as collaborative environment creation, using updated data, matching the stakeholders' expectations, communication transparency, proper implementation, and amending the necessary changes. Ribolde (2019) claimed the success factors as the assessment of the industry, competitors, and market trends, review of the vision and mission, identification of opportunities and threats, defining key initiatives and functional objectives, prioritization of goals, proper staffing, and budgeting.

\section{Challenges Faced during strategic Planning}

According to IC Thrive (2016), strategic planning is a process in which departments lack alignment and creativity becomes less. Rosenberg (2013) claimed the major challenges as the strategic plans mostly considered as a five-year plan book not as an approaching strategy, untangling organizational purpose and incorporation of reputation and the social definition of value. Guerra (2016) mentioned the common challenges facing strategic planning implementation as the identification of the starting point and the process owner, management of changes, support from the higher level, and technology. Aileron (2011) claimed that they mostly faced challenges as insufficient information about the work environment, absence of commitment and the right people especially the leaders, idle plans, unwillingness to amend changes, ignoring the market, mismatch of goals to resources, improper performance measures.

\section{Research Methodology}

The research adopted an exploratory-descriptive research design in general, as it aimed to answer the role of strategic planning in the construction companies in Oman. This research adopted a mixed approach, quantitative and qualitative approach where it used the quantitative technique to investigate the companies and identify the problem while the qualitative approach was used to explain the challenges and uncover the best practices followed by the companies. The survey questionnaire was used for the quantitative approach while the interview was used for the qualitative approach.

The research used the cross-section time horizon data. The snapshot - cross-section time horizon was the most common type of research and dissertations. According to the Tender board in Oman, there were 940 companies registered as local companies in the category of construction and maintenance, and subcategories of building and construction companies and the study tested 90 companies using the survey questionnaire and interviews with senior employees/the owners of the companies.

The study investigated how the company gained success and how it addressed the strategic planning issues. The research was triggered with the critical evaluation of the components of the strategic planning process involving five components of the strategic planning process: the mission, vision and aspirations, core values, objectives, strategies, and operational-tactics (Krach, 2016). The factors that lead to the success of strategic planning in construction companies were analysed as well. This research critically analysed these factors in the different categories of construction companies.

\section{Findings}

Table 1. Demographic Profile

\begin{tabular}{|c|c|c|c|}
\hline Company grade & Company age & Position & Degree of involvement \\
\hline Excellent (33) & $<5$ years $(5)$ & Leadership (19) & High (22) \\
\hline Grade 1 (23) & 5-10 years $(\mathbf{1 8})$ & Managerial (25) & Medium (41) \\
\hline Grade 2 (4) & 10-15 years $(\mathbf{2 6})$ & Operational (15) & Low (4) \\
\hline Grade 3 (5) & $>15$ years $(\mathbf{1 7})$ & Supervisorial (8) & Non (1) \\
\hline
\end{tabular}




\section{Company Grade}

The respondents were more in the high-grade companies and less in the lower grade companies. This reflects the degree of interest in the strategic planning of those companies. The results reflecting good communication channels, active management, and a good level of interest in strategic planning from High-grade companies.

\section{Company Age}

$39.39 \%$ of the companies were established between the years 2005-2010. 27.27\% between the years 2010 2015 , and only $7.58 \%$ over the last 5 years. This indicates that most of the companies taken under survey were established from 5 to15 years, i.e. these companies were established during the boom of the economy. This reflects that these companies were more interested in strategic planning, and the companies established over the last 5 years showed less interest in strategic planning. This is not a logical practice as new companies are more likely to have strategic planning in their businesses in the first stage of their business life. This could reflect the economic status and the unstable market and economic downturn in Oman over the last five years where companies could not make a clear projection of future businesses.

\section{Position}

Around $28.36 \%$ of the respondents were at the leadership level in their companies and $37.31 \%$ at the managerial level and only $11.94 \%$ were from the supervisory level. It is a good indication that they are responsible to create, approve, implement, and review the strategic plans within the companies. This high response from those levels reflects the understanding and interest in strategic planning. The percentage of the supervisory level is a good sign that the persons working at that level having more interest and knowledge in strategic planning.

\section{Degree of Involvement in Strategic Planning}

Most of the respondents (98.53\%) were involved at least once in a strategic planning process regardless of the degree of involvement. 32.35\% were responsible for strategic planning in their companies (the leaders, and consultants). $60 \%$ of them were the board of directors, managers, and heads of departments. $1.47 \%$ only were not at all involved in the strategic planning process.

Table 2. Knowledge about the Strategic Planning Components

\begin{tabular}{|l|c|c|}
\hline \multicolumn{1}{|c|}{ Answer choices } & Frequency & Percent \\
\hline Strongly agree & 20 & 29.41 \\
\hline Agree & 36 & 52.94 \\
\hline Neither agree nor disagree & 9 & 13.24 \\
\hline Disagree & 2 & 2.94 \\
\hline Strongly disagree & 1 & 1.47 \\
\hline
\end{tabular}

Most of the respondents $(82.35 \%)$ were aware of the strategic planning components. This is not a good indicator as there are still few companies that do not have clear components in their strategic plans and around $4.41 \%$ never knew their companies' strategic plan's components. This reflects that the companies do not spend enough effort to make all employees aware of the strategic plans and their components and this needs to be resolved and improved.

Table 3. Targets and Objectives Clarity in the Companies

\begin{tabular}{|l|c|c|}
\hline \multicolumn{1}{|c|}{ Answer choices } & Frequency & Percent \\
\hline Strongly agree & 19 & 27.94 \\
\hline Agree & 37 & 54.41 \\
\hline Neither agree nor disagree & 10 & 14.71 \\
\hline Disagree & 2 & 2.94 \\
\hline Strongly disagree & 0 & 0.00 \\
\hline
\end{tabular}

Most of the respondents are $(82.35 \%)$ have clear targets and objectives and it reflects a clear vision, good business plans in that company with well-defined objectives. $2.94 \%$ confirmed that they get clear objectives and targets. It is learned that the companies spend good efforts to clear the targets to the employees but needs to enhance such practice. 
Table 4. Targets Realisticity in the Companies

\begin{tabular}{|l|c|c|}
\hline \multicolumn{1}{|c|}{ Answer choices } & Frequency & Percent \\
\hline Realistic & 52 & 76.47 \\
\hline Neither Realistic nor not Realistic & 15 & 22.06 \\
\hline Not Realistic & 1 & 1.47 \\
\hline
\end{tabular}

Most of the respondents $(76.47 \%$ ) have realistic targets and it is a healthy indicator of good strategic planning components. $1.47 \%$ reported that their targets are not realistic. They are not using the right persons in the right place or the planning team plan does not have enough knowledge about strategic planning.

Table 5. The Integration and Balance of the Strategic Planning Components

\begin{tabular}{|l|c|c|}
\hline \multicolumn{1}{|c|}{ Answer choices } & Frequency & Percent \\
\hline Strongly agree & 15 & 22.06 \\
\hline Agree & 47 & 69.12 \\
\hline Neither agree nor disagree & 5 & 7.35 \\
\hline Disagree & 1 & 1.47 \\
\hline Strongly disagree & 0 & 0.00 \\
\hline
\end{tabular}

Most of the respondents $(91.18 \%)$ agreed that the target is very important. Only $1.47 \%$ did not agree that they are getting integrated i.e. the components are balanced and integrated with the construction companies in Oman.

Table 6. Support to Achieve Target

\begin{tabular}{|l|c|c|}
\hline \multicolumn{1}{|c|}{ Answer choices } & Frequency & Percent \\
\hline Strongly agree & 20 & 29.41 \\
\hline Agree & 35 & 54.41 \\
\hline Neither agree nor disagree & 10 & 14.71 \\
\hline Disagree & 2 & 2.94 \\
\hline Strongly disagree & 1 & 1.47 \\
\hline
\end{tabular}

Most of the respondents $(80.88 \%)$ agreed that they are getting the required support to achieve the targets. Only $4.41 \%$ disagreed that they did not get any support from their management to succeed. i.e., there is a small lack of leadership skills in the construction companies in Oman.

Table 7. Commitment to Strategy

\begin{tabular}{|l|c|c|}
\hline \multicolumn{1}{|c|}{ Answer choices } & Frequency & Percent \\
\hline Strongly agree & 18 & 26.47 \\
\hline Agree & 41 & 60.29 \\
\hline Neither agree nor disagree & 5 & 7.35 \\
\hline Disagree & 4 & 5.88 \\
\hline Strongly disagree & 0 & 0.00 \\
\hline
\end{tabular}

Most of the respondents $(86.76 \%)$ agreed that the important factors to success were there in the strategic plans and $7.35 \%$ were not sure about the management commitment. 5.88\% reported that the management did not commit to the strategic plans. The high percentage shows that a high commitment to the strategic plans is reflecting the good awareness about the strategic planning practices and importance.

Table 8. Engaging a Key Person from Each Level in Strategic Planning Activities

\begin{tabular}{|l|c|c|}
\hline \multicolumn{1}{|c|}{ Answer choices } & Frequency & Percent \\
\hline Strongly agree & 9 & 13.24 \\
\hline Agree & 42 & 61.76 \\
\hline Neither agree nor disagree & 10 & 14.71 \\
\hline Disagree & 4 & 5.88 \\
\hline Strongly disagree & 3 & 4.41 \\
\hline
\end{tabular}

Most of the respondents (75\%) agreed that their companies engaged a key person from each level in planning activities and $14.71 \%$ were neutral. 
Table 9. Innovation Environment Status

\begin{tabular}{|l|c|c|}
\hline \multicolumn{1}{|c|}{ Answer choices } & Frequency & Percent \\
\hline Strongly agree & 15 & 22.06 \\
\hline Agree & 31 & 45.59 \\
\hline Neither agree nor disagree & 12 & 17.65 \\
\hline Disagree & 10 & 14.71 \\
\hline Strongly disagree & 0 & 0.00 \\
\hline
\end{tabular}

$67.65 \%$ agreed that the companies reflected a healthy innovative work environment and it provides an important factor for success in the strategic plans. $17.65 \%$ were neutral. $14.71 \%$ disagreed as there might be a lack of innovation in their companies.

Table 10. Getting the Benefit From the Historical Data

\begin{tabular}{|l|c|c|}
\hline \multicolumn{1}{|c|}{ Answer choices } & Frequency & Percent \\
\hline Strongly agree & 23 & 38.82 \\
\hline Agree & 37 & 54.41 \\
\hline Neither agree nor disagree & 4 & 5.88 \\
\hline Disagree & 4 & 5.88 \\
\hline Strongly disagree & 0 & 0.00 \\
\hline
\end{tabular}

Most of the respondents (93.23\%) agreed that their companies using the historical data in their future planning and $5.88 \%$ were neutral. $5.88 \%$ did not agree. Without the historical data, the strategic plan will not get executed successfully.

Table 11. Measuring and Evaluating the Performance

\begin{tabular}{|l|c|c|}
\hline \multicolumn{1}{|c|}{ Answer choices } & Frequency & Percent \\
\hline Strongly agree & 15 & 22.06 \\
\hline Agree & 36 & 52.94 \\
\hline Neither agree nor disagree & 9 & 13.24 \\
\hline Disagree & 7 & 10.29 \\
\hline Strongly disagree & 1 & 1.47 \\
\hline
\end{tabular}

Most of the respondents (75\%) agreed that their companies measuring and evaluating the performances and $13.24 \%$ were neutral. $11.53 \%$ disagreed which might lead to a delay in achieving the targets and the implementing of the plans.

Table 12. Creating a Sense of Urgency to Implement the Strategic Plans

\begin{tabular}{|l|c|c|}
\hline \multicolumn{1}{|c|}{ Answer choices } & Frequency & Percent \\
\hline Strongly agree & 12 & 17.65 \\
\hline Agree & 36 & 52.94 \\
\hline Neither agree nor disagree & 15 & 22.06 \\
\hline Disagree & 5 & 7.35 \\
\hline Strongly disagree & 0 & 0.00 \\
\hline
\end{tabular}

$70.59 \%$ agreed that the companies created a sense of urgency and the need for implementing the strategic plan in their companies and $22.06 \%$ were not sure about the practice.

Table 13. Motivation Practices Exists

\begin{tabular}{|l|c|c|}
\hline \multicolumn{1}{|c|}{ Answer choices } & Frequency & Percent \\
\hline Strongly agree & 8 & 11.76 \\
\hline Agree & 37 & 54.41 \\
\hline Neither agree nor disagree & 17 & 25.00 \\
\hline Disagree & 5 & 7.35 \\
\hline Strongly disagree & 1 & 1.47 \\
\hline
\end{tabular}

$66.17 \%$ agreed that the motivation practices prevail in their companies to implement the strategies. $25 \%$ were neutral and $7.35 \%$ reported not getting any motivation. 
Table 14. Accepting New Process

\begin{tabular}{|l|c|c|}
\hline \multicolumn{1}{|c|}{ Answer choices } & Frequency & Percent \\
\hline Strongly agree & 12 & 17.65 \\
\hline Agree & 38 & 55.88 \\
\hline Neither agree nor disagree & 12 & 17.65 \\
\hline Disagree & 6 & 8.82 \\
\hline Strongly disagree & 0 & 0.00 \\
\hline
\end{tabular}

$73.53 \%$ agreed that the companies welcome new processes. $17.65 \%$ were neutral and $8.82 \%$ reported disagreement.

Table 15. Efficiency and Transparency

\begin{tabular}{|l|c|c|}
\hline \multicolumn{1}{|c|}{ Answer choices } & Frequency & Percent \\
\hline Strongly agree & 17 & 25.00 \\
\hline Agree & 28 & 41.18 \\
\hline Neither agree nor disagree & 18 & 26.47 \\
\hline Disagree & 4 & 5.88 \\
\hline Strongly disagree & 1 & 1.47 \\
\hline
\end{tabular}

$66.18 \%$ agreed that the communication channels were efficient and transparent making a healthy working environment. $26.47 \%$ were neutral and $7.35 \%$ disagreed. The disagreement might be due to bureaucracy and complex communication channels.

Table 16. IT Strategy to Support the Company's Strategic Plans

\begin{tabular}{|l|c|c|}
\hline \multicolumn{1}{|c|}{ Answer choices } & Frequency & Percent \\
\hline Strongly agree & 17 & 25.00 \\
\hline Agree & 36 & 52.94 \\
\hline Neither agree nor disagree & 10 & 14.71 \\
\hline Disagree & 4 & 5.88 \\
\hline Strongly disagree & 1 & 1.47 \\
\hline
\end{tabular}

77.94\% agreed that their companies support using new technology. $14.17 \%$ were neutral and $7.35 \%$ disagreed. This disagreement might be due to the companies did not have any IT strategy.

\section{Qualitative Analysis}

The Researcher had interviews with senior persons in a construction company in Oman and the summary of the interviews are as follows:

\section{General Manager in A $1^{\text {st }}$-Grade Company}

\begin{tabular}{|l|l|l|}
\hline$\#$ & \multicolumn{1}{|c|}{ Question } & \multicolumn{1}{c|}{ Answers } \\
\hline 1 & $\begin{array}{l}\text { Opine the role of strategic } \\
\text { planning in construction } \\
\text { companies in Oman? }\end{array}$ & It is the main element to survive in the market \\
\hline 2 & $\begin{array}{l}\text { How to evaluate the } \\
\text { strategies? }\end{array}$ & $\begin{array}{l}\text { From the number of working hours without accidents and the } \\
\text { number of years without loans }\end{array}$ \\
\hline 3 & $\begin{array}{l}\text { What are the factors/ } \\
\text { elements required for the } \\
\text { strategic plans to be } \\
\text { successful in construction } \\
\text { companies? }\end{array}$ & $\begin{array}{l}\text { To aim for business diversification in various sectors. When } \\
\text { one sector gets into difficulty, the other sector will support the } \\
\text { company. The strategy needs to be comprehensive and } \\
\text { integrated. Suggested to start a business in e-mining, to use } \\
\text { most of its resources in both businesses. Diversification could } \\
\text { be also within the business such as carpentry workshops etc. }\end{array}$ \\
\hline 4 & $\begin{array}{l}\text { What are the challenges that } \\
\text { are faced in the } \\
\text { implementation of strategic } \\
\text { planning in construction } \\
\text { companies? }\end{array}$ & $\begin{array}{l}\text { 1. External - economic status of the country. } \\
\text { 2. Internal - unable to do accurate analyses of the internal and } \\
\text { external factors. }\end{array}$ \\
\hline
\end{tabular}


2. Chairman from an excellent Grade company

\begin{tabular}{|l|l|l|}
\hline$\#$ & \multicolumn{1}{|c|}{ Question } & \multicolumn{1}{c|}{ Answers } \\
\hline 1 & $\begin{array}{l}\text { Opine the role of strategic } \\
\text { planning in construction } \\
\text { companies in Oman? }\end{array}$ & $\begin{array}{l}\text { A strategy is a culture and not an event or a project, to } \\
\text { effectively reach everyone in the company. The strategy could } \\
\text { be a closing strategy and not necessarily be a developing } \\
\text { strategy. }\end{array}$ \\
\hline 2 & $\begin{array}{l}\text { How to evaluate the } \\
\text { strategies? }\end{array}$ & $\begin{array}{l}\text { 1. Success of the strategic planning is measured by three } \\
\text { elements viz. survive, competition and growth } \\
\text { 2. The companies should study the data of the last 3 years and } \\
\text { the forthcoming three years but with accuracy }\end{array}$ \\
\hline 3 & $\begin{array}{l}\text { What are the factors/ } \\
\text { elements required for the } \\
\text { strategic plans to be } \\
\text { successful in construction } \\
\text { companies? }\end{array}$ & $\begin{array}{l}\text { Good management is a must to support the employees in } \\
\text { implementing the plans along with the capable teamwork of } \\
\text { project managers, finance managers, etc. }\end{array}$ \\
\hline 4 & $\begin{array}{l}\text { What are the challenges that } \\
\text { faced in the } \\
\text { implementation of strategic } \\
\text { planning in construction } \\
\text { companies? }\end{array}$ & $\begin{array}{l}\text { 1. External - some small new companies are competing to get } \\
\text { big projects and these companies have less overhead and } \\
\text { expenses. This leads the big companies to lose their chances to } \\
\text { get the job work with a reasonable profit. This practice is not } \\
\text { good to accept such contractors. } \\
\text { 2. Internal - resistance to change and new ideas. }\end{array}$ \\
\hline
\end{tabular}

\section{Chief engineer in excellent Grade company}

\begin{tabular}{|l|l|l|}
\hline$\#$ & \multicolumn{1}{|c|}{ Question } & \multicolumn{1}{c|}{ Answers } \\
\hline 1 & $\begin{array}{l}\text { Opine the role of strategic } \\
\text { planning in construction } \\
\text { companies in Oman? }\end{array}$ & $\begin{array}{l}\text { Any company aiming to continue in the market and } \\
\text { competition should adopt a clear strategy }\end{array}$ \\
\hline 2 & $\begin{array}{l}\text { How to evaluate the } \\
\text { strategies? }\end{array}$ & from the number of projects completed \\
\hline 3 & $\begin{array}{l}\text { What are the factors/ } \\
\text { elements required for the } \\
\text { strategic plans to be } \\
\text { successful in construction } \\
\text { companies? }\end{array}$ & $\begin{array}{l}\text { Adopt new technology of building like 3D printing } \\
\text { technology and using the other new equipment. } \\
\text { 2. The strategy needs to consider external parties (the suppliers } \\
\text { as well) and always precautionary efforts to avoid delay due to } \\
\text { shortage of materials etc. }\end{array}$ \\
\hline 4 & $\begin{array}{l}\text { What are the challenges that } \\
\text { are faced in the } \\
\text { implementation of strategic } \\
\text { planning in construction } \\
\text { companies? }\end{array}$ & $\begin{array}{l}\text { 1. External - (national) relation between the company and the } \\
\text { country. Internal - financial and human resources (as strategic plans } \\
\text { were subdivided into departmental sub-plans). }\end{array}$ \\
\hline
\end{tabular}

\section{Company owner for Grade two company}

\begin{tabular}{|l|l|l|}
\hline$\#$ & \multicolumn{1}{|c|}{ Question } & \multicolumn{1}{c|}{ Answers } \\
\hline 1 & $\begin{array}{l}\text { Opine the role of strategic } \\
\text { planning in construction } \\
\text { companies in Oman? }\end{array}$ & $\begin{array}{l}\text { Strategic planning is not widely applied in all construction } \\
\text { companies. Many times the companies discount so much and } \\
\text { ignore the profitability just to survive in the market }\end{array}$ \\
\hline 2 & $\begin{array}{l}\text { How to evaluate the } \\
\text { strategies? }\end{array}$ & Through profitability \\
\hline 3 & $\begin{array}{l}\text { What are the factors/ } \\
\text { elements required for the } \\
\text { strategic plans to be } \\
\text { successful in construction } \\
\text { companies? }\end{array}$ & $\begin{array}{l}\text { 1. Might be due to the clear vision, diversification, and due to } \\
\text { dynamic efforts } \\
\text { 2. The alignment with the national strategy will get the } \\
\text { company a big chance to get support from the government. }\end{array}$ \\
\hline 4 & $\begin{array}{l}\text { What are the challenges that } \\
\text { are faced in the } \\
\text { implementation of strategic } \\
\text { planning in construction } \\
\text { companies? }\end{array}$ & $\begin{array}{l}\text { 1. External - property developers forming construction } \\
\text { companies to develop their buildings on their own causing high } \\
\text { competition in the market. } \\
\text { 2. Internal - achieving the required review, profit, collection, } \\
\text { bad debt, cost-saving challenges, human resources. }\end{array}$ \\
\hline
\end{tabular}


Summary of findings

Most of the companies have a clear understanding of the strategic planning components. Companies put in great efforts to convey the company's goals and targets to their employees. Companies have realistic strategic plans but improvements need to be done to ensure success during implementation.

The results also revealed that the following success factors to strategic planning still needs revisiting and enhancement to ensure implementation success:

The motivation is not at the best level and the lack of creating a sense of urgency to implement the strategic plans needs to be enhanced. Other good factors were available like the commitment of managers and employees to the strategic plans. The involvement of key persons from all levels in the planning process, supporting innovation, the metric to measure and evaluates performance. It is also revealed that the challenges during the planning and implementation are due to a lack of motivational practices to encourage the employees to implement and stay committed to the plans, lack of transparency, and no efficient communication technique.

\section{Conclusion}

It was concluded that the strategic planning role in construction companies can be evaluated based on four strategic planning points viz. the right components, the success factors, addressing challenges; and the appropriate solutions to overcome challenges. Strategic planning is widely used in the different grades of construction companies in Oman, and this reflects the stability of the industry from the strategic aspect and will lead to the success of the construction which will eventually lead to economical social growth and development of the country.

It is also found that the components of strategic planning are well understood within the construction companies in Oman, and these components are integrated well in achieving the roles of strategic planning. The companies are showing good efforts in supporting innovation. There were strong commitments to strategic plans from the company managers and the involvement of key persons from all levels during the planning process. There is no problem with the new process created through strategic planning as they are aware of the external environment. The adopted strategies are flexible and simple and the companies are continuously adopting new technologies in implementing the same.

There was a lack of motivation, lack of transparency and efficiency of communications, and unfair competition between the big and small companies. It was reported that the property developers becoming contractors and taking a big cut from the market share by themselves. Some of the success factors required for strategic planning were not identified in most construction companies such as motivation systems. There are deficiencies in the follow-up mechanisms. There is a lack of sensitivity to implementing the strategic plans.

\section{Recommendations}

The general recommendation is to keep all the positive practices and adopt a good IT strategy to support the growth, the strong commitment to the strategic plans, involve key persons from all levels in the planning sessions, supporting innovation, the flexibility to adapt to the new process created, and the knowledge about the external environment and its effect, to enhance the role of the strategic planning.

\section{Recommendations to construction companies}

1. The companies need to use more realistic objectives in their plans.

2. The companies need to invest more in the training of the companies' leaders to increase their leadership skills.

3. The companies need to adopt an improved evaluation system to evaluate employees' performance to measure success and avoid delay.

4. The companies need to implement the plans to avoid delays and pending cases by encouraging and recognizing innovation.

5. Companies need to adopt a clear and fair motivation system to encourage the employees.

6. The companies need to adopt a clearer and effective communication channel and avoid bureaucracy to implement the strategic plans.

7. The companies need to request the government to make new legislation to protect the companies from unfair competition by small companies and property developers.

8. Companies can have an external consultant to avoid pressure on the in-house team from the routine work in preparing the strategic plan.

9. The companies need to be clear about their competitive advantage and decide whether their strategies are built on the price leading or differentiation. 


\section{Recommendation to the Government}

The success of the strategic plans of the construction companies will lead to the socio-economic growth of the country. One of the most important challenges facing construction companies is the unfair competition from some illegal contractors and small companies. The Government needs to amend the legislation accordingly.

\section{Recommendation to the Clients}

Any building owner or client is usually planning to build his building more cheaply, but the higher responsibility to anyone in this country is to support and protect the national, economic, and social growth. Using illegal contractors or using small companies for such big projects will affect the legal and the properlyestablished companies. Therefore, the client needs to choose the right companies for the projects and not deal with illegal contractors.

\section{References}

1. Aguila, C. (2015). Strategic Planning Leadership. Academia.edu, 1-12. https://www.academia.edu/35520524/Strategic_Planning_Leadership

2. Aileron (2011). 10 Reasons Why Strategic Planning Fails. Forbes. Retrieved from https://www.forbes.com/sites/aileron/2011/11/30/10-reasons-why-strategic-plans-fail/\#152766686a8b

3. Asakereh, A. \& Bahrani, T. (2012). Implementation of Strategic Planning in Organizations. Academia.edu, 2(2), 46-49.

4. Boateng, P. A., Amponsah, E. B., Akafo, V., \& Yamoah, P. (2015). Strategic Planning Process Formality: A Model. International Knowledge Sharing Platform, 7(26), 1-8.

5. Cakmak, P. I., \& Tas, E. (2012). Strategic Planning Practices of Contractor Firms In Turkey. ProcediaSocial and Behavioural Sciences, 58, 40-46. https://doi.org/10.1016/j.sbspro.2012.09.976

6. Chaudhry, I. S., Ali, S., Fareed, G., \& Fakher, A. (2012). Role of strategic planning in small business: An overview. International Journal of Management, IT and Engineering, 4(1), 316-324.

7. Cherniss, M. (2018, Feb.6, 2018). 6 Key Factors to Successful Strategic Planning. Blue Beyond Consulting. Retrieved from https://www.bluebeyondconsulting.com/2018/02/6-key-factorssuccessful-strategic-planning

8. Cherkaoui, H. (2020). Revealed: The Importance of Strategic Planning in Construction Companies and Projects. LetsBuild. Retrieved from https://www.letsbuild.com/blog/revealed-the-importance-ofstrategic-planning-in-construction-companies-and-projects

9. Dalum, M. (2018, Sep.25, 2018). The Biggest Challenges to Strategy Implementation. Acadal. Retrieved from https://acadal.com/the-5-biggest-challenges-to-strategy-implementation/

10. Guerra, H. (2016). Commune Challenges and Recommendations for Strategic Planning. Cipher Business Solution. Retrieved from https://www.cipherbsc.com/challenges-strategic-planning/

11. Haythem, A. (2015). The Role of Strategic Planning In Performance Management. Express as International Journal of Multi-Disciplinary Research, 2(3), 1-12.

12. IC Thrive (2016, Oct.13, 2016). The 5 Challenges of Creating a Strategic Planning Process. Retrieved from https://icthrive.com/blog/the-5-challenges-of-creating-a-strategic-planning-process

13. Jayawarna, S. \& Dissanayake, R. (2019). Strategic Planning and Organization Performance: A Review on Conceptual and Practice Perspectives. Archives of Business Research, 7(6), 155-163. http://doi.org/10.14738/abr.76.6684

14. Jurevicius, O. (2013, Feb 13, 2013). Strategic Management \& Strategic Planning Process. Strategic Management Insight. Retrieved from https://strategicmanagementinsight.com/topics/strategic-planningprocess.html

15. Krach, K. (2016, Sep.6, 2016). 5 Key Components of a Powerful Strategic Plan. Medium. Retrieved from https://medium.com/@ KeithKrach/5-key-components-of-a-powerful-strategic-plan-4fbb6f15eae3

16. Lotich, P. (2019, May 15, 2019). The 5 Steps Process of Strategic Planning. The Thriving small business. Retrieved from https://thethrivingsmallbusiness.com/strategic-planning-process/

17. Ofori, G., \& Toor, S. U. R. (2012). Leadership and Construction Industry Development in Developing Countries. Journal of Construction in Developing Countries, 17.

18. Olsen, E. (2016). Major Components of a Strategic Plan. Business Strategy, Dummies. John Wiley \& sons. https://www.dummies.com/business/business-strategy/major-components-of-a-strategic-plan/

19. Perkins, K. (2020). The Top 10 Strategic Planning Best Practices. On Strategy. Retrieved from https://onstrategyhq.com/resources/the-top-10-strategic-planning-best-practices/

20. Ribolde, J. (2019). The Seven Keys to Successful Strategic Planning. Forbes. Retrieved from https://www.forbes.com/sites/forbescoachescouncil/2019/06/27/the-seven-keys-to-successful-strategicplanning/\#7fc2e03f5497 
21. Rosenberg, J. (2013, Jun.5, 2013). Three Strategic Planning Challenges. Field Notes - Observations and Insights from NAS, Retrieved from https:/www.artsjournal.com/fieldnotes/2013/06/three-strategicplanning-challenges/

22. Rouse, M. J., \& Daellenbach, U. S. (1999). Rethinking Research Methods for the Resource-Based Perspective: Isolating Sources of Sustainable Competitive Advantage. Strategic management journal, 20(5), 487-494. htps://doi.org/10.1002/(SICI)1097-0266(199905)20:5<487::AIDSMJ26>3.0.CO;2-K

23. Sage, S. (2020). The Three-Level of Strategy. Onstrategy. https://onstrategyhq.com/resources/the-threelevels-of-strategy/

24. Taylor, A. (2016, Jan.16, 2016). what is the strategic planning process? SME Strategy Management Consulting. Retrieved from https://www.smestrategy.net/blog/what-is-the-strategic-planning-process

25. Vo, E. (2019, Jan.4, 2019). What are the Key Components of Strategic Plan? Strategic Planning. The Hartford. Retrieved from https://sba.thehartford.com/business-management/key-components-ofstrategic-plan/

26. Watson, M. (2016). Six Characteristics of Successful Strategic Planning. LinkedIn. Retrieved from https://www.linkedin.com/pulse/six-characteristics-successful-strategic-plans-mike-watson

27. Workfront (2020). How to Write a Strategic Plan? Workfront, https://www.workfront.com/projectmanagement/life-cycle/planning/strategic-plan

Copyright: ( 2021 by the authors. Licensee Global Scientific Publications, Oman.

This work is licensed under a Creative Commons Attribution-ShareAlike 4.0 International License.

This is an open-access journal and the articles published in this journal are distributed under the terms of CC-BY-SA. 